\title{
ІДЕЇ ГУМАНІЗМУ В ТВОРЧОСТІ ЯКОВА КОЗЕЛЬСЬКОГО
}

\author{
М.Й. Заремський
}

Загальновідомим є те, що гуманізм як система поглядів та принцип поведінки формувався вже на ранніх етапах класово-державного трансформування суспільства, і його осмислення як найвищої цінності, котра має інтегральний характер для спільноти в цілому та всіх їі прошарків, здійснювалося у межах спеціалізованих форм духовного виробництва - філософії та релігії. Завдяки їх особливому статусу і особливим можливостям впливати на мораль в концептуальні засади осмислення суспільного розвитку як найважливіша компонента була втілена думка про самоцінність, унікальність, неповторність людського життя як такого, поза статевими, віковими, етнічними, становими, майновими та іншими відмінностями між людьми.

Ця гуманістична тенденція була властива й для вітчизняної філософської думки минулих часів, особливо у XVIII столітті, коли розуміння гуманізму, його природи не було звуженим (як це відбулося пізніше) рамками однобокого класового підходу. Враховуючи це, а також й ту обставину, що з початком епохи Просвітництва в Європі XVIII століття з'являється позарелігійна концепція суспільного прогресу (Вольтер, Гоббс, Руссо, Тюрго, Кондорсе та інші), і беручи до уваги, що гуманістичні пошуки у такому ж напрямку ведуться й на вітчизняному грунті (Г. Сковорода, Я. Козельський, В. Золотницький), вартим уваги було б співставлення поглядів західноєвропейських та вітчизняних мислителів на розуміння місця і ролі людини в суспільстві, а відтак - гуманізму.

Певна робота в цьому напрямку здійснена дослідниками філософ-

Актуальні проблеми духовності 
ської творчості Г. Сковороди ${ }^{1}$. Цього аж ніяк не можна сказати про аналітичне опрацювання творчого доробку нашого видатного співвітчизника - «прологу» (як кваліфікував його О.Пріцак) ${ }^{2}$ у розвиткові української філософії, яскравого представника нового (цілком відмінного від сковородинівського софійного) - епістемного типу мислення - Якова Павловича Козельського (близько 1728-після 1795). Розробці просвітницьких ідей (гуманізму - зокрема) присвячений головний твір цього видатного українця - «Філософічні пропозиції» (1768), певною мірою - його остання велика робота «Міркування двох індійців Калана і Ібрагіма про людське пізнання» (1788) - як реакція на широку кампанію боротьби проти просвітницьких ідей, як антимасонський твір.

Що ж стосується написаних у 50-60-ті роки минулого століття статей та монографій, присвячених Козельському ${ }^{3}$, то вони або лише частково зачіпають проблеми гуманістики, розробки просвітницьких ідей, або витлумачують та оцінюють їх з позицій соціально-класових ідеологем того періоду.

Завданням нашої статті є не тільки спроба більш грунтовного висвітлення місця і ролі Я.П.Козельського у розробці гуманістичних ідей, але й намагання встановити вітчизняні пріоритети у цих питаннях, загальнолюдське не тільки не заперечує, але й проявляє себе у формі національного. У цьому зв'язку нам близька думка І. Ільїна: «Людина може віднайти загальнолюдське лише таким чином: поглибити своє духовно-національне лоно до того рівня, де живе духовність, зрозуміла для всіх віків і народів» ${ }^{4}$.

\footnotetext{
${ }^{1}$ Див. напр.: Багалій Д. Г. Сковорода: Український мандрований філософ.Харків, 1926; Драч І.Ф., Кримський С.Б., Попович М.В. Григорій Сковорода. - Київ., 1984; Іванъо І.В. Філософія і стиль мислення Г. Сковороди. - К., 1983; Махновець Л. Григорій Сковорода: Біографія. - К., 1972; Петров Н.И. Первый малороссийский период жизни и научно-философского развития Григория Сковороды. ТКДА, 1902. - № 12; Сковорода Григорій. Дослідження, розвідки, матеріали.-К., 1992; Сумцов М.Ф. Сковорода і Ерн. - Літературно-науковий вісник, 1918. - Кн. 1 та ін.

${ }^{2}$ Прічак О. Доба військових канцеляристів // Київська старовина. - 1993. - № 4.

${ }^{3}$ Див. напр.: Демичев В.А. Я.П. Козельский о предмете философии и класификации наук // Вопросы философии. - 1958. - № 4; Дмитриченко В.С. Суспільнополітичні погляди Я.П. Козельського. - К., 1957; Коган Ю.Я. Просветитель XVIII века Я.П. Козельский. - М., 1958; Щипанов И.Я. Общественно-политические и философские воззрения русских просветителей второй половины XVIII века // Очерки по истории философской и общественно-политической мысли народов СССР. Т. 1. - М., 1955 та ін.

${ }^{4}$ Ильин И.А. Путь к очевидности.-М., 1993.-С. 245.
} 
Як це випливає вже з передмови до «Філософічних пропозицій», проблема благополуччя і щастя народу хвилювала Я. Козельського 3 тієї причини, що прагнення, тяга до благополуччя, на його думку, є «природне право» всіх людей, хоча, «незважаючи на це, небагато з них ним користуються».

Український мислитель підкреслює, що у вирішенні кардинальних проблем гуманістики він приєднується до табору французьких філософів XVIII століття. Аналізуючи їх ідеї, Козельський водночас виступає як самостійний оригінальний мислитель: він творчо, критично переробив все те краще, що було в західноєвропейській думці, намагаючись використати передові ідеї для вирішення завдань суспільного життя Pociï.

Особливо прихильним було ставлення Я.П. Козельского до Ж.-Ж. Руссо - за його словами, - «бессмертия достойного мужа, как высокопарного орла, превзошедшего всех бывших до него философов» ${ }^{5}$. Аби висловити це, потрібно було мати неабияку сміливість: ще за 5 років до надрукування «Філософічних пропозицій» книги Руссо було заборонено розповсюджувати в Росії.

На формування суспільно-політичних поглядів Козельського великий вплив справили також Дідро, Монтеск'є, Гельвецій. Але, виступаючи як самостійний і оригінальний мислитель, Я. Козельский, як він сам пише, «не ласкал никому из других авторов, каков бы он велик ни был, потому что раболепствующий мнениям других людей равно глуп кажется в глазах мудрого человека» ${ }^{6}$. Завдяки цьому український філософ зміг в ряді питань подолати недоліки своїх попередників і висловити ряд нових ідей.

Незважаючи на те, що дуже важливим для вченого Яків Козельський вважає заглиблення в «натуру речей», все ж основне завдання він вбачає у пошуку «правил благополуччя». Це положення задекларовується вже з перших фраз твору - у зверненні до читача, котрим започатковуються «Філософічні пропозиції: «Ежели рассудить о намерении, с которым мы обучаемся наукам, то философия между ними заслуживает особливое уважение, не столько для содержания в ней оснований ко всем другим наукам, сколько для правил к исканию благополучия» ${ }^{7}$. Не менш важливим, вважає автор, є й пошук «к до-

\footnotetext{
${ }^{5}$ Козелъский Я.П. Философические предложения. Предисловие // Избранные произведения русских мыслителей второй половины XVIII века. - T. 1. - М.: Госполитиздат, 1952.- С. 418.

6 Там же.

${ }^{7}$ Там же.- C. 412 .
} 
стижению его [благополуччя - M.3.] пристойных средств» ${ }^{8}$. Іншими словами, предметом особливої уваги Я.П. Козельського є етичні та соціально - політичні проблеми як складові його практичної філософії.

Присвячені етиці сторінки «Філософічних пропозицій» Козельського як за формою, так і за змістом вигідно відрізняються від традиційних для того часу повчань, витриманих в дусі настанов на всі випадки життя.

Як відомо, широке розповсюдження в XVIII ст. як на Заході, так і в Росії отримала теорія «природного права». Застосовані до сфери етики, їі положення дозволили здійснити серйозний крок у справі емансипації моралі від релігії, проголосивши принципи природного походження і розумного пояснення моралі.

Теорія «природного права» стала ареною гострих дискусій у середовищі представників Просвітництва XVIII століття, де предметом суперечок було те, чи здатність розуміти добро і зло (закладена, на думку деяких просвітників, в самій людській природі) навіяна Богом, чи людина сама обходиться без допомоги Творця. Свою філософську позицію у цьому питанні Козельський висловлює наступним чином: «Философы рассуждают о свойствах и делах Божиих, а мне думается, что это они предпринимают излишнее и несходное с силами их разума дело. Священное писание проповедует нам в божестве непостижимую умом нашим премудрость, беспредельное всемогущество, вечность бытия, неприкосновенность, необъятность и правую волю, то есть склонность к благодеянию и правосудию и отвращение от всех неправостей, чего для нас и довольно, а более покушаться на непонятное умом нашим, кажется, некстати» ${ }^{9}$. Заявляючи про свою відмову розмірковувати про властивості і справи Божі, український філософ спонукає нас до висновку про його, принаймні, релігійний індиферентизм, про прагнення до кінця розмежувати філософію і психологію, про наявність у поглядах Я. Козельского деїстичних тенденцій.

Зовсім інша позиція з цього питання властива сучасникам Козельского - В. Золотницькому, Г. Теплову та іншим. Вважаючи, як і Козельський, своїм головним завданням пошук шляхів до благополуччя людей, Володимир Золотницький, наприклад, писав: «Все гражданские от разумных и Богом данных нам монархов, также и церковные от мужей природных и откровенных разумом наполнил их предписанными законами, суть точно божественные» ${ }^{10}$. А звідси, у повній від-

\footnotetext{
${ }^{8}$ Там же.

9 Там же. - C. 417

10 Золотницкий B. Состояние человеческой жизни. . - СПб., 1763. - С. 31.
} 
повідності з духом зазначеного, - позиція, що іменується «непротивленням злу - насильством»: якщо тебе образили, - повчає Золотницький, - «то уступи ему и дай место его злобе» ${ }^{11}$. Тут ми також маємо нагоду в черговий раз переконатися, наскільки значним був авторитет не тільки «першої філософії» вольфіанця Х. Баумейстера, кінцеве завдання якої полягало в обгрунтуванні буття Бога і безсмертя душі ${ }^{12}$, але й настанов його моральної філософії, згідно з якою слід думати про ворогів наших так, ніби вони нас нічим не скривдили; якщо ж кривдник робить замах на наше життя, то в крайньому випадку можна чинити спротив, але так, щоб він був «самомалейший» і кривдник «никакого вреда ... не потерпел» ${ }^{13}$.

Яків Козельський, працюючи з квітня 1766 року на посаді секретаря 3-го департаменту Сенату (в 60-х pp. XVIII ст. цей департамент відав справами по Україні, Прибалтійському краю, а також по Академії наук і Московському університету), мав можливість глибоко ознайомитися $з$ юридично-правовим та матеріальним становищем селянства, висловити власний погляд на «селянське питання», яке саме з цього періоду набувало дедалі більшої гостроти й актуальності в політиці самодержавства і суспільно-політичній думці. Нами вже наводилися документальні свідчення про становище кріпаків і сваволю поміщиків у період царювання Катерини $\mathrm{II}^{14}$, що, без сумніву, наклало відбиток на ті морально-етичні позиції, які відстоював видатний український філософ Козельський у питаннях суспільного прогресу, свободи особистості, гуманізму, на особливі риси, що вирізняли його погляди. Він не був моралістом у прямому значенні цього слова. Одначе за моралістичним матеріалом його творів проглядає досить чітка і творчо продумана система етики - одна з перших в історії вітчизняного Просвітництва XVIII ст. У своїх етичних поглядах він не тільки повною мірою стоїть на рівні передових систем епохи, але й розвиває і поглиблює їх положення з урахуванням обставин часу, принципів та порядків, що панували в Росії.

Глибокий знавець філософських ідей «енциклопедистів» - Гельвеція, Гольбаха, Дідро, Монтеск'є, Руссо (заочну полеміку з останнім він розпочинає вже у передмові до «Філософічних пропозицій»), наш

\footnotetext{
11 Там же. - С. 107.

$12[Ф] Х$. Баумейстер. Метафизика. - М., 1764.-С. 10.

13 [Ф.]Х. Баумейстер Нравоучительская философия. - СПб., 1764. - С. 142-147.

14 Див.: Заремсъкий М.Й., Чирва В.Ф. Погляди Якова Козельского у контексті філософської думки в Україні XVIII ст. // Глухів і Глухівщина в історії українського національного відродження. - К.: Ін Юре. - 1999. - С. 76-77.
} 
співвітчизник не мислив собі етику поза політикою і політику поза етикою. Для нього «політика» в системі «моральної філософії» означала «практику доброчинності»; іншими словами, якщо охарактеризована у вузькому значенні слова етика покликана вияснити, у чому повинні

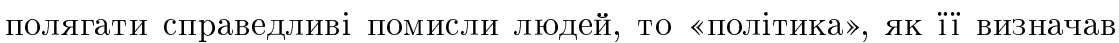
Козельський, «есть наука производить праведные намерения самыми способнейшими, и притом праведными средствами в действо» ${ }^{15}$. Отже, це означало, що політика, як її розумів Козельський, зобов'язана продемонструвати людям основні принципи ідеального (або, принаймні, близького до ідеального) суспільного устрою.

Логіка міркувань українського філософа засвідчує, що він, не відкидаючи можливостей особистого морального вдосконалення, все ж вважає цей шлях недостатнім; для нього, як і для французьких матеріалістів, головним чинником, що впливає на поведінку людини, $є$ суспільне середовище.

Гуманістична спрямованість поглядів Я. Козельського особливо яскраво демонструється в розділі «Філософічних пропозицій», присвяченому трактуванню відповідних «прямій доброчесності» суспільних поглядів. «Что касается до добродетели, - писав він, — то я ее люблю, почитаю выше всех других качеств, раболепствую перед нею, и жертвую ей все тем, что нахожу приятнейшего на свете, одним словом, я ее обожаю» ${ }^{16}$.

Проте мислитель застерігає від спрощеного розуміння «істинного людинолюбства» : філософи в усі часи немало міркували про доброчинність, але біда їх була в тому, що вони «не досліджували і не виводили назовні» всіх «прихованих підробок і підступностей людських». Тим часом саме в ім'я любові до людей і потрібно розкривати їм очі на ті шляхи, якими «входять в життя» вади, і перш за все, найзгубніша серед них - лицемірно приховане «пригноблення ближніх ${ }^{17}$. I нема такої великої жертви, яку було б негоже покласти на вівтар загальнолюдського благополуччя.

Співставляючи розум і доброчинність, Козельський беззаперечно віддавав перевагу останній. Досвід історії, вважав він, засвідчує, що одного вдосконалення у розумі, якому люди до цих пір віддавали стільки сил і уваги і яке принесло людству неоціненну користь, недостатньо:

\footnotetext{
${ }^{15}$ Козелъский Я.П. Философические предложения // Избранные произведения русских мыслителей второй половины XVIII века.-T.1.-M.: Госполитиздат, 1952. - C. 141.

${ }^{16}$ там же. - Передмова.

17 там же. - С. 201.
} 
людина, позбавлена доброчинності, буде неминуче застосовувати силу свого розуму не на благо, а на шкоду людям. I якщо, - розвивав Я.П. Козельский свою думку, - «простий лиходій» шкідливий для благополуччя суспільства, то лиходій «вчений» «уже не только будет несносен, но и совсем его погубить может» ${ }^{18}$.

Отже, прогрес в доброчинності є, згідно з Козельським, вирішальною умовою благополуччя людей.

Що ж таке «істинна доброчинність» $з$ точки зору Якова Козельського? Зрозуміти це можна лише звернувшись до всієї концепції його етики. Вихідні теоретичні положення етики українського філософа грунтуються на засадах, згідно з якими поведінка людини в суспільстві спонукається не вродженими моральними ідеями, а обумовлюється двома чинниками: її природними біологічними особливостями і середовищем, під безпосереднім впливом якого людина перебуває впродовж усього свого життя. Тут позиція українського філософа мало чим відрізняється від поглядів сучасних йому просвітників. Визначаючи сутність першого з названих факторів, Козельський поділяє точку зору K.А. Гельвеція (співставляючи їі з позицією Р. Декарта і віддаючи перевагу у такому співвідношенні гельвеціанству) щодо притаманної людині здатності відрізняти корисне від шкідливого, «добра от худа» як виразу природних її потреб. Козельський засвідчує цю позицію прямим посиланням на книгу Гельвеція «Про розум» (1758): для нього, як і для французького філософа-матеріаліста, такі пристрасті, як заздрість, гордість, скупість, честолюбство тощо мають в своїй основі первинний потяг до задоволення («Благополучие, - пише Я.П. Козельський, - есть не что иное, как постоянное удовольствие и такой предмет, к которому все люди без изъятия самопроизвольно стремятся...» $\left.{ }^{19}\right)$. Одначе якісної визначеності вони набувають ззовні, в результаті «сожития человеческого».

У світлі цих поглядів на рушійні сили людської діяльності український мислитель підводить нас до думки, що саме прагнення до щастя шляхом переслідування у своїх вчинках особистого інтересу і особистої користі й конкретизує прагнення до благополуччя і відвернення від страждань. Отже, з точки зору інтересу, користі оцінює людина як свої вчинки, так і вчинки інших. Що для людини корисне, те для неї й моральне, вважає Козельський. Слідом за Гельвецієм він стверджує: «Приятность или польза есть у многих людей единственный су-

\footnotetext{
18 Там же.-С. 195.

${ }^{19}$ Козелъский Я.П. Философические предложения. Предисловие. - СПб., 1768. C. 56 .
} 
дья разума и добродетели» ${ }^{20}$. Звідси цілком логічною виглядає позиція Козельського відносно характеру моралі: його теорія інтересу (яка цілком на рівні поглядів Гельвеція, Гольбаха, Дідро) поєднує тезу про постійну природу схильності людини до благополуччя з минущими, змінними впливами середовища.

Однак визнання відносного характеру моралі не могло задовольнити гуманіста Козельського, який прагнув обгрунтувати загальнолюдську «науку искания благополучия» - «прямую добродетель», - котра не зазнає змін, не залежить від звичаїв, тобто має не відносний, а абсолютний характер. Чи не вступає в суперечність із задекларованою раніше думкою про відносний характер моралі намагання філософа Козельского все ж знайти (зрозуміти і описати) «пряму доброчинність»? - Аж ніяк. Хоча, - зазначав він, - така доброчинність до цих пір ніде не «сыскивалась», покликання філософа - підтримувати віру людей в торжество справедливості, краще майбутнє людства.

Звернімо увагу на одне місце з «Філософських пропозицій» Козельського: «На сих рассуждениях основавшись, разделяю я по примеру господина Гельвеция [мова йде про твір останнього «Про розум»M.3.] добродетель и разум на прямые, или философские или всемирные, и на приближительные к прямым, как то на народные, то есть, целого какого народа, на общественные, то есть малого какого общества, и особенные, то есть каждого человека особо» ${ }^{21}$. Виходить, природа «істинної доброчинності» подвійна: з одного боку, в ній міститься особистий інтерес, а з іншого - інтерес людства, до якого особистість належить і від якого залежить. Яків Козельський [твір українського мислителя написаний у трактатній формі - M.3.] пункти від 288 до 364 своїх «Філософічних пропозицій» присвячує ідеї гармонізації особистих і загальних інтересів. Ці думки українського мислителя найбільш яскраво виражаються в розділі «Юриспруденція» його головного філософського твору. Вже саме визначення права - «основание всякого доброго и беспристрастного, то есть ни худого, ни доброго в рассуждении всех чувствующих тварей дела [виділено нами - M.3.] называю я правом или правостию, или справедливостью» ${ }^{22}-$ вказує на бажання Козельского знайти певну вихідну категорію в його міркуваннях про всезагальну мораль. Правильно зрозуміле «право» в своєму загальному формулюванні не може бути, згідно з Козельським, несправедливим. Однак на практиці закон далеко не завжди вкладається у схеми

\footnotetext{
20 Там же.

${ }^{21}$ там же. - С. 160

22 там же. - С. 71.
} 
цих загальних формулювань «права», і тому дуже часто не має нічого спільного із справедливістю.

Таким характером відзначається, в найбільш загальних рисах, концепція «істинної доброчинності» Якова Павловича Козельського. Як бачимо, вона має багато спільного з етичними вченнями діячів французького Просвітництва Вольтера, А.-Р. Тюрго, Ж.-А. Кондорсе, Ж.Ж.Руссо, Д.Дідро та інших. В той же час ця етична система мала ряд особливих рис. В їі основі лежать все ті ж два фактори: природна людина і середовище, де у їх координації вирішальну роль, за Козельським, відіграє саме середовище, призначення якого - переплавляти особисте, егоїстичне, обмежене прагнення кожної людини до благополуччя у справді альтруїстичне ставлення до своїх вчинків.

Отже, визнаючи важливу і навіть вирішальну роль середовища i виховання в процесі формування морального обличчя людини, український філософ зауважує, що іноді одними й тими ж обставинами породжуються зовсім різні у моральному відношенні індивіди. Тут погляди Козельського співпадають з позицією Дідро у його полеміці з Гельвецієм (останній, як відомо, розвивав принцип, згідно з яким люди виходять з майстерні природи рівними один одному за своїми інтелектуальними задатками): середовище, як майстерний скульптор, формує мораль людини і веде її по шляху доброчинності чи пороків; але при цьому потрібно брати до уваги природні дані індивіда, які можуть або сприяти, або протидіяти цьому середовищу. Висловившись, що «все народы на свете суть брение, а скудельники [гончарі - M.3.] его правительства» ${ }^{23}$, Козельський велику увагу звертає на якість самого «брения». Відсутність в людини вроджених моральних почуттів ще не означає, що при всіх інших рівних умовах люди однаково чутливі до тих моральних уроків, які дає середовище. Тут філософ стверджує, що окрім виховання, на моральні якості людини впливають такі особливості як темперамент, розум, властивості волі. До цих характерних для етичних засад Козельского моментів належить також його погляд на індивідуальне виховання як засіб розвитку властивостей розуму i духу людини і створення тим самим додаткових умов морального вдосконалення (ще раз підкреслимо, що основні умови мислитель пов'язував з перетворенням і вдосконаленням соціального середовища).

Побіжно зупинимося на педагогічних поглядах Якова Козельского, які доповнюють розуміння гуманістичної позиції мислителя, оскільки педагогіка в його системі-це практика певної філософії. Він надає

${ }^{23}$ Там же.- C. 198. 
найважливішого значення моральному вихованню i, послідовно розвиваючи свою точку зору, рішуче виступає за застосування його в ролі основи і першого кроку виховного процесу в сім’ї і школі. «При воспитании детей,- пише Козельский, - родителям должно прежде их усиливать в добродетели» ${ }^{24}$. Потрібно, зазначає він, «стараться о воспитании в публичных училищах детей прежде в добронравии, а потом в разуме» 25 .

Переконаність Козельського в позитивних наслідках запропонованого ним морального виховання зовсім не спиралась на таку ж тверду переконаність щодо можливостей практичного втілення відповідних заходів в рамках існуючого ладу.

Український мислитель, не шкодуючи фарб, демонструє читачеві всю глибину моральної деградації сучасного йому суспільства, в якому панує принцип «людина людині- вовк». «Что может быть несносней, - запитує він, - того распространенного мнения, которое оправдывает приобретение личного благополучия за счет страданий и несчастий ближних? И что же удивительного, если в этом обществе даже сама добродетель оказывается чуть ли не преступлением, способным навлечь на человека ненависть и гонения окружающих, в то время как на порок смотрят или сквозь пальцы, или - и то хуже-даже почитают в нем некую доблесть?» ${ }^{26}$. Багато сторінок твору присвячує Козельський викладу правил «практичної» моралі, що грунтується як на власних спостереженнях, так і на запозичених із творів Ларошфуко, Гельвеція та інших авторів.

Однак, може сам суспільний стан в його цивілізованих формах є в принципі порочним, і з цієї точки зору єдиною втіхою філософа має стати мрія про повернення до «золотого віку»? Це питання повинно було постати перед Козельським так само неминуче, як і перед іншими просвітниками.

Сам Козельський визнає, що ще в юності він захоплювався творами Ж.-Ж.Руссо, знаходив у себе «несколько сходно с его мыслями», що науки, хоча й приносять користь тому, хто ними користується, коли потрапляють в «погані руки», можуть спричиняти й шкоду. Однак це, як він писав, «оторопление духа» продовжувалось з ним недовго: «размысля, что ежели порочить науки злом, то доведется почитать все вещи на свете худыми» 27 , наш співвітчизник «преодолел согла-

\footnotetext{
24 Там же. - С. 133.

25 Там же. - С. 203.

26 Там же. - С. 166.

${ }^{27}$ Козельский Я.П. Рассуждения двух индийцев Калана и Ибрагима о человече-
} 
сное с Руссо проклятие наук и оглашение их орудиями всякого зла и вреда» ${ }^{28}$, усвідомивши, що все зло і вся шкода - від поганого їх застосування. Іншими словами, Козельський тут дуже близько підійшов до своєї ідеї про співвідношення розуму і доброчинності.

Я.П. Козельський не береться спростовувати думку Руссо про «натуральний стан» як «найкорисніший» для роду людського. Однак він підкреслює, що як тільки люди, в силу невідомих причин, втратили свій «натуральний спокійний стан», натомість вони отримали різноманітні потреби, які задовольнялися наукою і мистецтвом. I тому нема ніякого сенсу шукати доброчинність в минулому. Так само безглуздо і навіть шкідливо думати, ніби наука і мистецтва самі по собі, за своєю сутністю, приховують зерна пороків. Вся справа полягає в їх застосуванні, характер якого залежить від пануючих в суспільстві звичаїв, порядків, законів. Не в самій «суспільності», а саме у «зловживанні нового цього стану» й вбачає Козельський причини усіх людських бід. В ньому, у цьому «Зловживанні», яке виступало в формі несправедливих порядків, законів, звичаїв, вбачав він основну перешкоду «прямій доброчинності». Знищення цих основ існуючих порядків й убачалось для українського мислителя Якова Павловича Козельського необхідною умовою для сходження людства на вершину доброчинності.

ском познании. Предисловие.-СПб., 1788. - C. III-IV.

${ }^{28}$ Там же. 